\title{
INVESTIGATION ON BANK STABILTY IN THE NILE RIVER AT Km 552.4 D.S ASWAN DAM
}

\author{
Samir A. S. Ibrahim \\ Hydraulics Research Institute, National Water Research Centre, Egypt.
}

\begin{abstract}
Higher current velocities associated with the release of emergency discharges downstream High Aswan Dam may cause degradation in the entire bed of some reaches, particularly in river banks of bend outer curve where many cities and villages are located. Consequently, a severe damage to agricultural properties, urban areas and roads is expected. To overcome such expected damage, velocity profile redistribution is of crucial important to decrease the current values of river bend, protection works against local scour and bank erosion is of crucial important. The purpose of this study is to develop a solution to stop the western bend bank erosion and partial failure in reach at km 552.4 D.S. Aswan Dam. There are two groins perpendicular to the western bank and three big scour holes in the area of about $1200 \mathrm{~m}$ long and $100 \mathrm{~m}$ width near the western bank along Salam village, $10.5 \mathrm{~km}$ D.S Assuit Barrage. Mathematical model was used to simulate the entire reach of $2.8 \mathrm{~km}$ on the Nile River at that area. To improve the flow condition by decreasing the water velocity at the western bank (outer bend), the existing condition during 2008 and four different suggested scenarios were simulated on the model. These scenarios were, removing the located groin, filling the lower part of areas (the scour holes) located at the western part to a level of 40.0 $\mathrm{m}$ above MSL, filling the bed and dredging the channel in areas closer to the scour hole until level of $40.0 \mathrm{~m}$ above MSL and extending the second groin from $10 \mathrm{~m}$ to $60 \mathrm{~m}$ length in addition to filling the lower part of scour hole to level of $40.0 \mathrm{~m}$ above MSL. The results were compared with the existing condition.
\end{abstract}

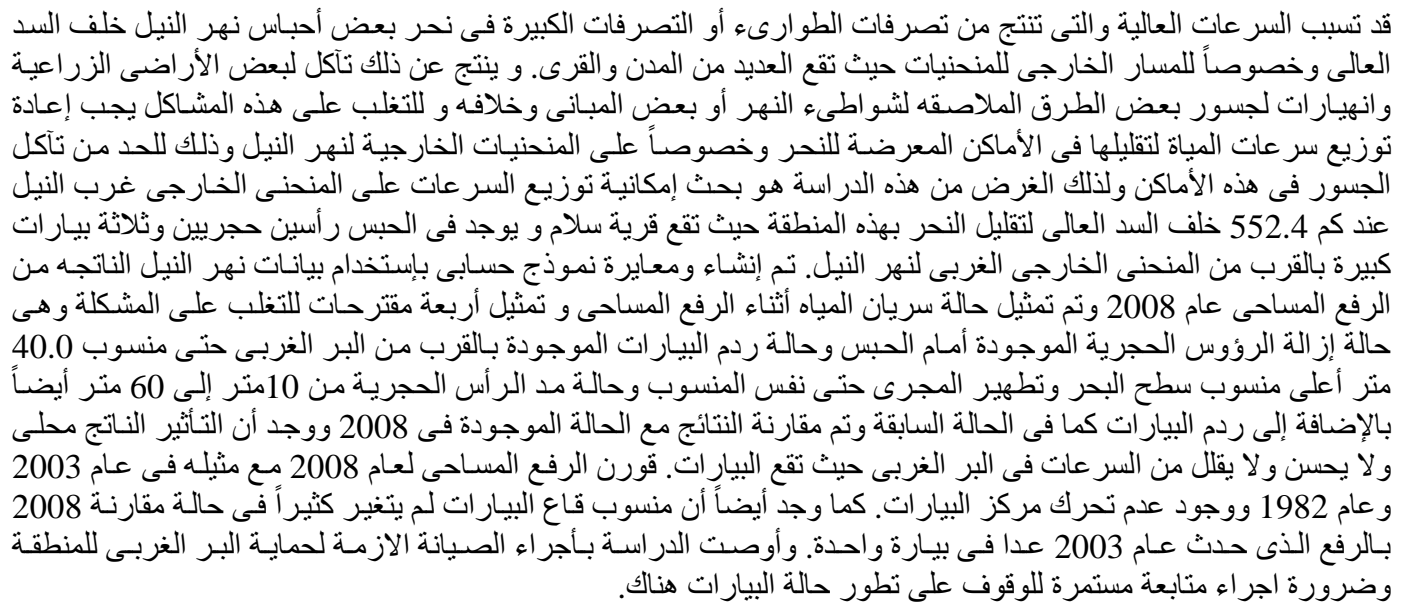

Keywords: Bank failure, Stability, Scour hole, Bank protection, Bend, Sinuosity.

\section{INTRODUCTION}

Rivers are broadly classified as straight, meandering or braided. Any change imposed on a river system may change its plan form geometry. Straight river channel has small sinuosity at bankfull stage. At low stage, the channel develops alternate sandbars, and the thalweg meanders around the sandbars in a sinuous fashion. Straight channels are considered a transitional stage to meandering, since straight channels are relatively stable only where sediment size and load are small, gradient, velocities, and flow variability are low, and the channel width-depth ratio is relatively low. There is little relation between degree of sinuosity, as considered apart from other properties, and lateral channel stability. A highly meandering river channel may have a lower rate of lateral migration than a sinuous channel of similar size. Assessment of stability is based mainly on 
additional properties, especially on bar development and the variability of channel width, HEC 20 (1995). The Nile River in Egypt is relatively straight with some sinuous reaches over short distances, which are related to a steeper slope. The increase in sinuosity appears to occur with a slope in excess of $10 \mathrm{~cm} / \mathrm{km}$. Steeper portions of the river appears to be more active and bank erosion should be expected to continue in these areas. The meander wavelength of the present River Nile ranges from approximately $2500 \mathrm{~m}$ to $4500 \mathrm{~m}$. It appears that the meander pattern subsequent to the construction of the Aswan High Dam (H.A.D.) is changing as a result of a reduction in discharge and sediment load. There are low amplitude meanders of the river, associated with the growth of alternate point bars and islands, and not meanders that materially change the main riverbank alignment, HRI (2005).

From examination of maps and air photo according to RNDP (River Nile Development Project), 1989, it is concluded that the river should be segregated into reaches that can be termed "Geomorphic reaches" as proposed to a simple separation at the barrages. Geomorphic reaches indicate the relationship of the pattern and width of a river to the valley in which the river flows and, therefore, is related to river bank erosion. The river has grouping into seven distinct geomorphic reaches having varying degrees of lateral constraint (limits to river shifting), Description of Geomorphic Reaches are summarized in Table 1.

Table 1, Description of Geomorphic Reaches from Aswan to Mediterranean Sea

\begin{tabular}{|c|c|c|c|}
\hline $\begin{array}{l}\text { Geomorphic } \\
\text { reach }\end{array}$ & Description & $\begin{array}{c}\text { Channel } \\
\text { pattern }\end{array}$ & Sinuosity \\
\hline Km 0-100 & $\begin{array}{l}\text { Confined by } \\
\text { valley wall }\end{array}$ & Straight & 1.05 \\
\hline Km 100-194 & $\begin{array}{l}\text { Partially } \\
\text { confined }\end{array}$ & $\begin{array}{l}\text { Straight to } \\
\text { gentle } \\
\text { meander }\end{array}$ & 1.04 \\
\hline Km 194- 470 & unconfined & Meandering & 1.47 \\
\hline Km 470 - 545 & $\begin{array}{c}\text { Confined by } \\
\text { valley wall } \\
\text { and towns on } \\
\text { left }\end{array}$ & Straight & 1.08 \\
\hline Km 545 - 580 & $\begin{array}{l}\text { Partially } \\
\text { confined }\end{array}$ & Meandering & 1.38 \\
\hline Km 580 - 960 & $\begin{array}{c}\text { Confined by } \\
\text { valley wall } \\
\text { and towns on } \\
\text { left } \\
\end{array}$ & $\begin{array}{l}\text { Straight with } \\
\text { gentle } \\
\text { meandering }\end{array}$ & 1.10 \\
\hline Nile Delta & $\begin{array}{c}\text { Deltaic } \\
\text { distributary } \\
\text { channels }\end{array}$ & Meandering & -- \\
\hline
\end{tabular}

A comprehensive analysis of the fluvial characteristics of the River Nile has been accomplished by the RNDP Project (RNDP, 1991a, 1992b). Before the construction of H.A.D., the peak flows were quite constant down the river but after building H.A.D., the peak flows decrease significantly downstream as irrigation water is withdrawn.

The bed material load is composed mostly of fine to medium sand with small amounts of silt. Before the construction of HAD, a portion of the bed material load was lost to the flood plain. This amount has reduced substantially due to the creation of Lake Nasser upstream HAD.

During high floods, the water managers in the Ministry of Water Resources and Irrigation may release discharges greater than the annual maximum discharge in an average year. These high discharges released from HAD are determined according to the regulation guidelines for operating the High Aswan Dam. These peak discharges may cause damages to the water control structures along the Nile and its branches. Relatively high discharges cause local scour near bridges, banks, harbors and other structures. Also, relatively high discharges may cause inundation to former flood plains that are currently in use. Such inundation may cause damage to agricultural properties, urban areas, roads and may put human lives into danger

\section{CASE STUDY}

\subsection{Description of the Study Area}

Salam village is located on the western bank at about $552.4 \mathrm{~km}$ downstream Aswan Dam and $10.5 \mathrm{~km}$ downstream Assuit Barrage. The village extends along reach of $1.2 \mathrm{~km}$ on the outer curve of the River Nile. Figure 1 satellite image shows the location of Salam.

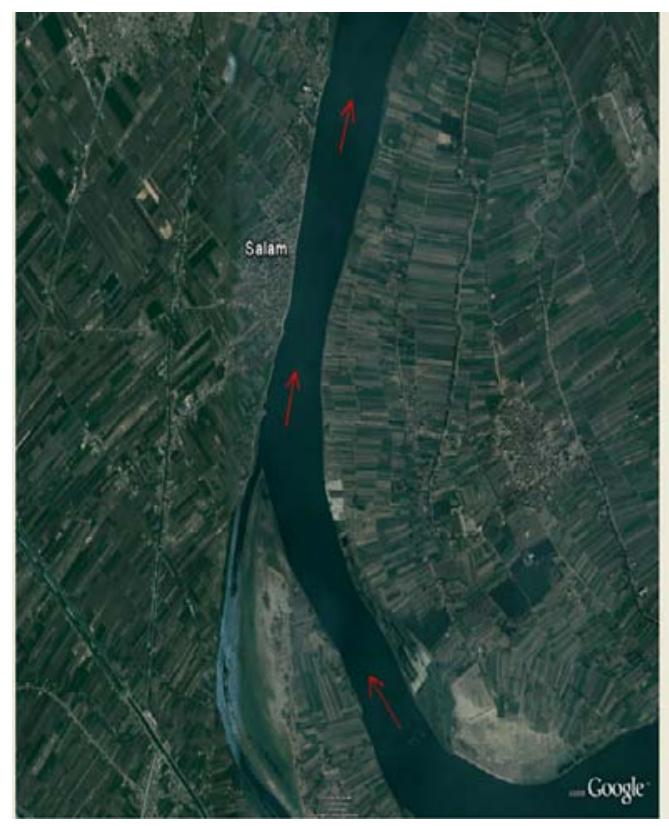

Fig.1 Satellite image show the location of Salam Village Located on the Nile 
The western bank side slope is 1:1 up to bank height of $3 \mathrm{~m}$. There is $4 \mathrm{~m}$ berm width at bank height of 3 $\mathrm{m}$ followed by another berm of $2.0 \mathrm{~m}$ width, then side slop of 1:1 until $1 \mathrm{~m}$ below the minimum water level. The bank was bitched by line stone from period more than 15 years ago. Some holes and small failure in the bank were appeared as shown in the Photo. 1.

\subsection{Purpose of the Study}

The purpose of the study is to stop the bank failure in this area with a view to develop a solution to the problem of bank erosion and partial bank failure.

\subsection{The Hydrographic Survey Results and Analysis}

Hydrographic survey was carried out, by HRI in 2008, to a reach of $1.2 \mathrm{~km}$ fronting the Salam village in addition to an extension of $1.6 \mathrm{~km}$ upstream and downstream of the village, making a total surveyed reach of $2.8 \mathrm{~km}$. The contour map generated from the field survey is shown in Figure 2 and 3 . The following was noticed:

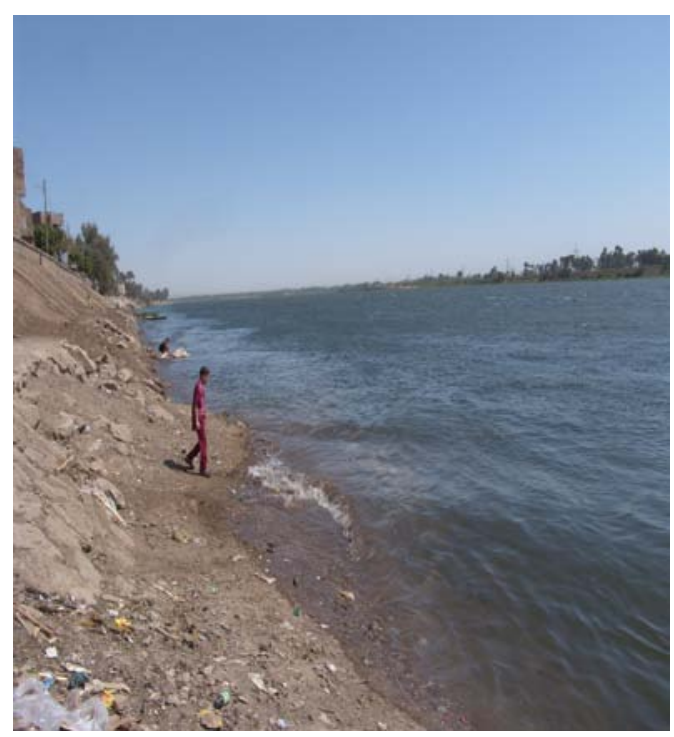

Photo 1. General view of the bank with some stones for bank and toe protection

The width of the river at that part is very narrow where it reaches to $300 \mathrm{~m}$. The average bed levels at the middle and eastern side of the reach range from $40 \mathrm{~m}$ to $43 \mathrm{~m}$ above MSL. There are three big scour holes in the area of about of $1200 \mathrm{~m}$ long and $100 \mathrm{~m}$ width near to the western bank along the village. The first hole has two centers and is located between cross sections No 8 and No 10. The lowest point of it is $36 \mathrm{~m}$ above MSL. The second hole also has two centers and is located between cross sections No 12 and No 14. The lowest point of it is $35 \mathrm{~m}$ above MSL. The third one is located between cross sections
No 17 and No 18. The lowest point of it is $25.5 \mathrm{~m}$ above MSL.

There are two groins perpendicular to the western bank of the river reach. The first groin with a length of $25 \mathrm{~m}$ at section No 8 which caused local scour reached at the surrounded area to level of $33.50 \mathrm{~m}$ above MSL. The second groin has a length of $10 \mathrm{~m}$ at section No. 12.

The water levels at that reach range between $43.0 \mathrm{~m}$ and $46.75 \mathrm{~m}$ above mean sea level during minimum and maximum discharge, respectively. Maximum discharge down stream Assuit Barrage is $2130 \mathrm{~m} 3 / \mathrm{s}$ which was recorded in a year 2002. Analyzing the two measured velocity cross sections (sections B\&E), it was found that the average velocity up and downstream the reach are 0.92 and $0.88 \mathrm{~m} / \mathrm{s}$, respetively, Figures (9\&10). The bed material samples appeared that D50 at the bed of this area is $0.384 \mathrm{~mm}$.

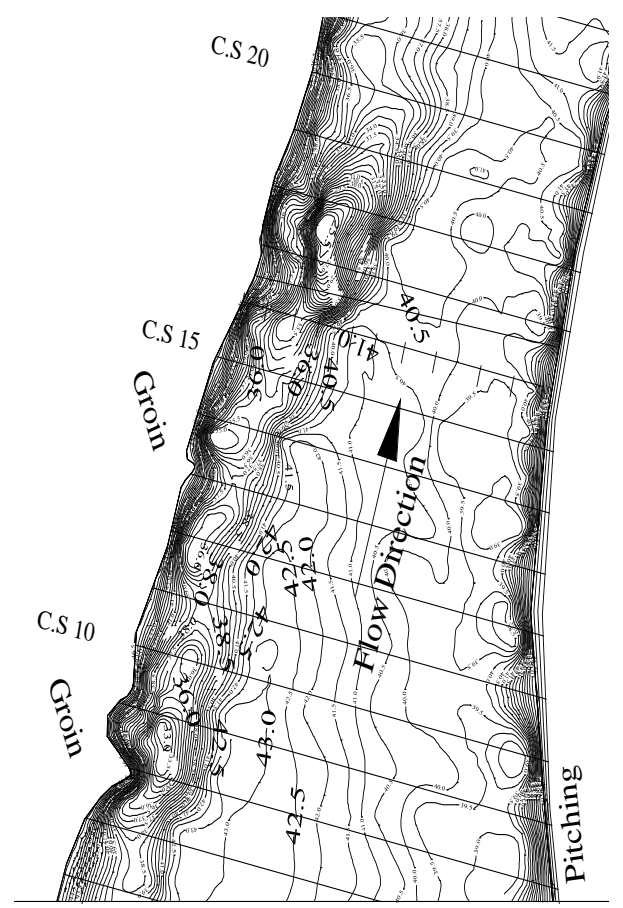

Fig.2 Contour map of the surveyed area 2008 (from C.S. 6 to 21)

\subsection{Comparison of the Scour Holes at Years 2008, 2003 and 1982}

Comparing the bed profile resulting from contour map of 2008 with that one resulting in 2003 and 1982 appeared that, the three scour holes existed before 2003, the centre of the holes did not move until 2008 and little change was occurred in the scour depth from 2003 to 2008. Big change in the scour depth was occurred from 1982 to 2003. The Figures No 4 to No 8 show comparison between the bed level at years 2008, 2003 and 1982 at sections 8, 9, 13, 16 and 17. 


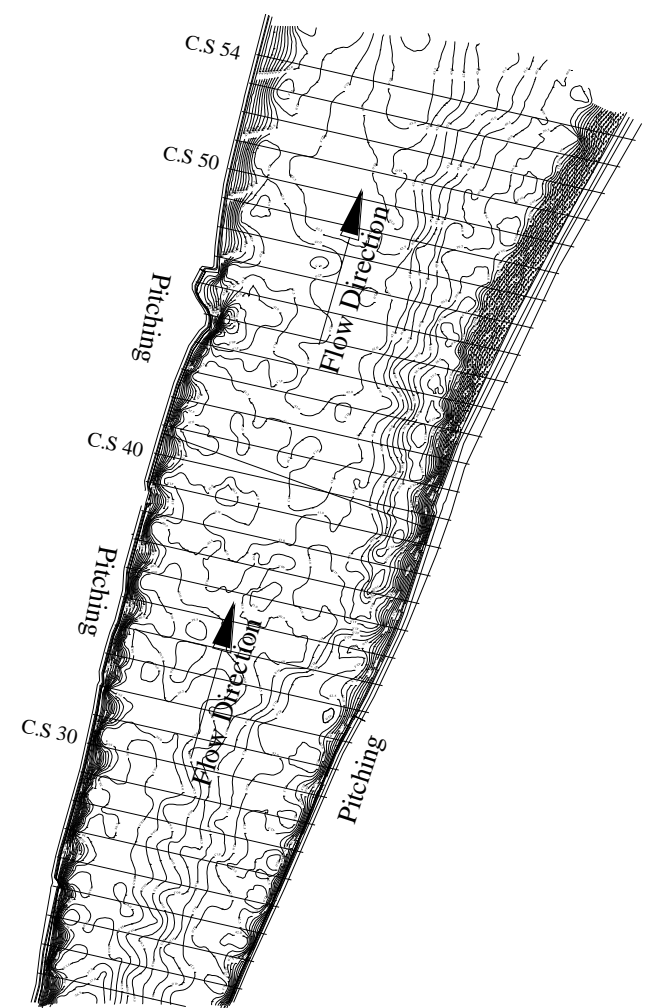

Fig.3 Contour map of the surveyed area 2008 (from C.S. 22 to 54 )

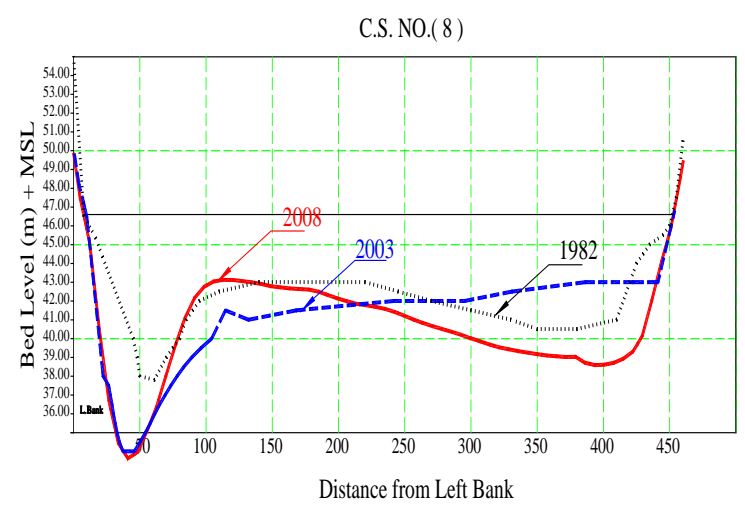

Fig.4 Comparison between the bed level at years 2008, 2003 and 1982 at C. S 8

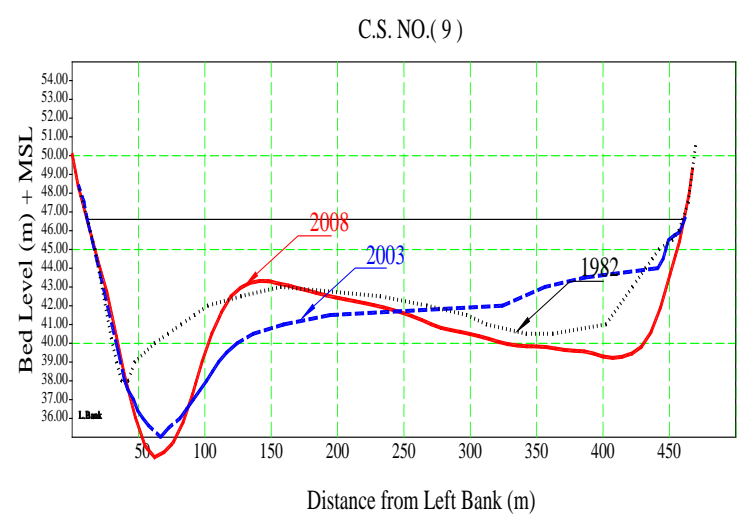

Fig.5 Comparison between the bed level at years 2008, 2003 and 1982 at C. S 9
C.S. NO.(13)

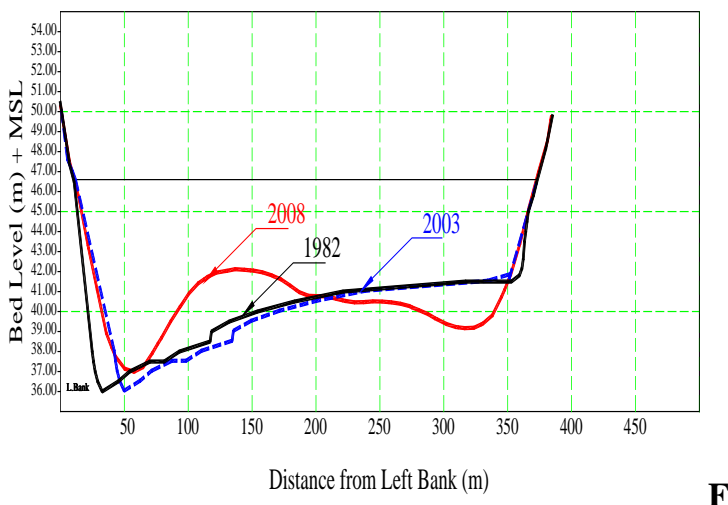

ig.6 Comparison between the bed level at years 2008, 2003 and 1982 at C. S 13

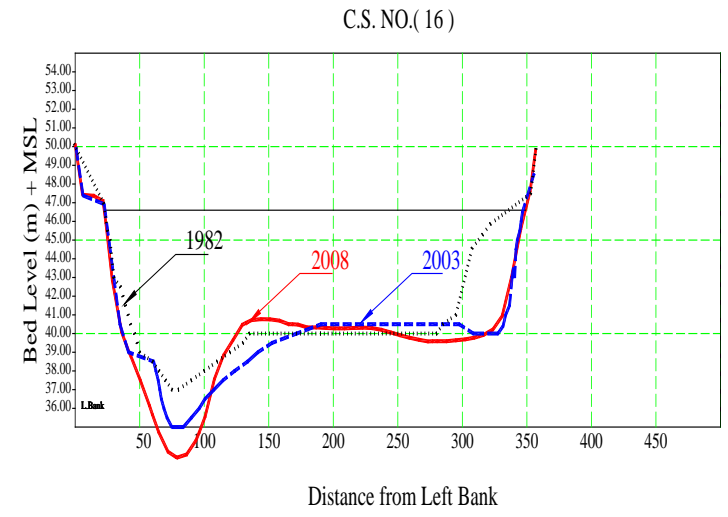

Fig.7 Comparison between the bed level at years 2008, 2003 and 1982 at C. S 16

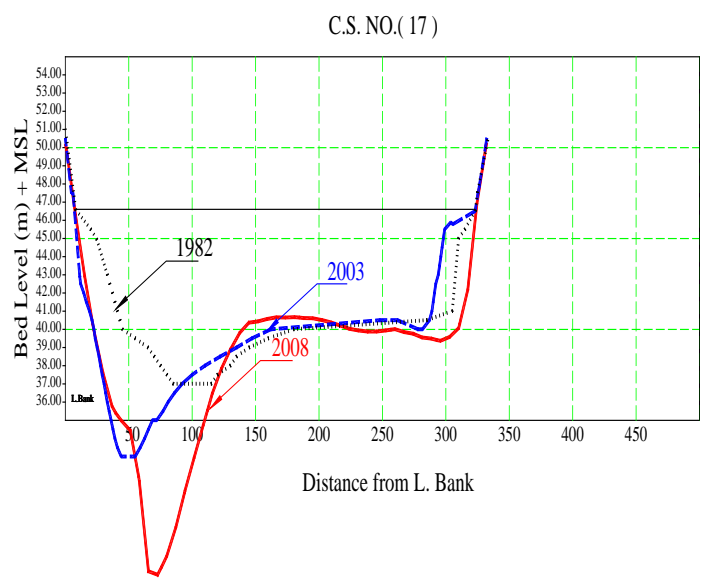

Fig.8 Comparison between the bed level at years 2008, 2003 and 1982 at C. S 17

\section{METHODOLOGY}

\subsection{Numerical Model}

In order to stop the bank erosion and the deepening scour holes, the water velocity at the eroded bank should be reduced. So, it is required to use a tool to simulate the reach and show the values of the velocity in the existing reach at different flow 
conditions. This was done to compare the existing velocity with the corresponding result after simulating the proposed solution. The Delft-3D program, which has been developed by Delft Hydraulics, the Netherlands, was employed to model the entire reach at Salam.

\subsection{Model Construction}

The total length of the simulated reach is about 2.80 $\mathrm{km}$. It includes the area of the river which has the bank failure in additional to enough distance up and downstream it. A curvilinear grid was designed with fine grid size ranges between 5 and $18 \mathrm{~m}$. The depth file was created based on the hydrographic survey data. The recent bathymetric survey of 2008 was implemented. The initial conditions were set by giving suitable values to the water levels, the velocity components in both the longitudinal and lateral directions. The discharge was used as an upstream boundary and the water level as a downstream boundary. The hydraulic roughness coefficient was defined at each grid point. Chezy coefficient was varied in the range of (40 to $70 \mathrm{~m}^{1 / 2} / \mathrm{s}$ ). The suitable time step and the total simulation time were defined in such away to achieve steady state condition.

\subsection{Model Calibration}

The water surface slope was adjusted in the model by changing the Roughness Coefficient until a similar slope to the prototype was obtained. The discharges of 1732.6 and $2067.9 \mathrm{~m}^{3} / \mathrm{s}$ were used for calibration of sections $\mathrm{B}$ and $\mathrm{E}$ respectively. The measured velocity profiles at sections $\mathrm{B}$ and $\mathrm{E}$ were compared with those resulting from the numerical model. According to this comparison, change in roughness coefficient at some grids was occurred until good agreement was achieved between the measured and resulting velocities at sections $\mathrm{B}$ and $\mathrm{E}$ as shown in Figures 9 and 10.

\subsection{Simulating Different Scenarios}

In order to decrease the velocity beside the western bank, different scenarios were simulated separately on the program as follows: (a) existing condition, (b) remove the located groin at section No 8, (c) filling the lower part of areas (the scour holes) located at the western part to a level of $40.0 \mathrm{~m}$ above MSL, (d) filling the bed and dredging the channel in areas closer to the scour hole until level of $40.0 \mathrm{~m}$ above MSL and (e) extending the second groin from $10 \mathrm{~m}$ to $60 \mathrm{~m}$ length in addition to filling the lower part of scour hole to level of $40.0 \mathrm{~m}$ above MSL. Level 40.0 $\mathrm{m}$ was preferred as dredging and filling level because it is convenient for navigation.

The program was run at the above mentioned scenarios at the river discharge of $2066 \mathrm{~m}^{3} / \mathrm{s}$ and corresponding water level of $46.55 \mathrm{~m}$ above MSL. The result velocities of these scenarios were compared by their corresponding of the existing condition. This was done by identifying 4 cross sections distributing over the whole reach to have the abovementioned comparison. The location of these 4 cross-sections is shown in Figure 11. The results as a comparison with existing condition are shown in Figures 12 to 16 .

The same runs were done for the existing conditions and the above mentioned scenarios at the maximum excepted river discharge of $4050 \mathrm{~m}^{3} / \mathrm{s}$ and corresponding water level of $48.89 \mathrm{~m}$ above MSL.

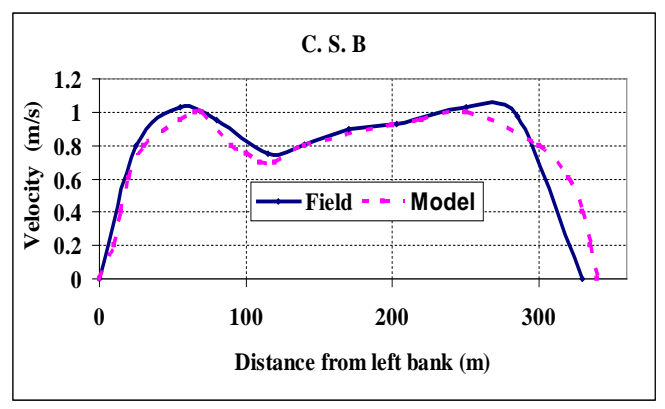

Fig.9 Measured and the simulated velocity at C. S B

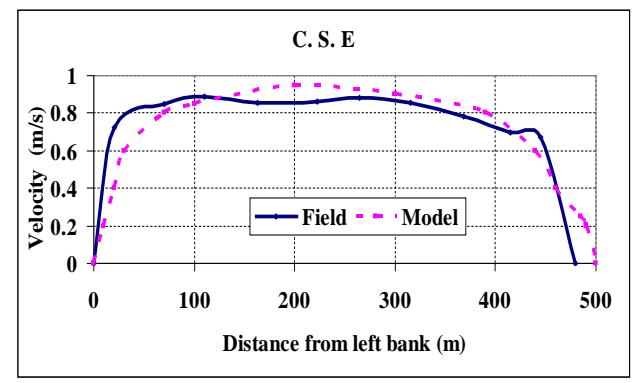

Fig.10 Measured and the simulated velocity at C. S E

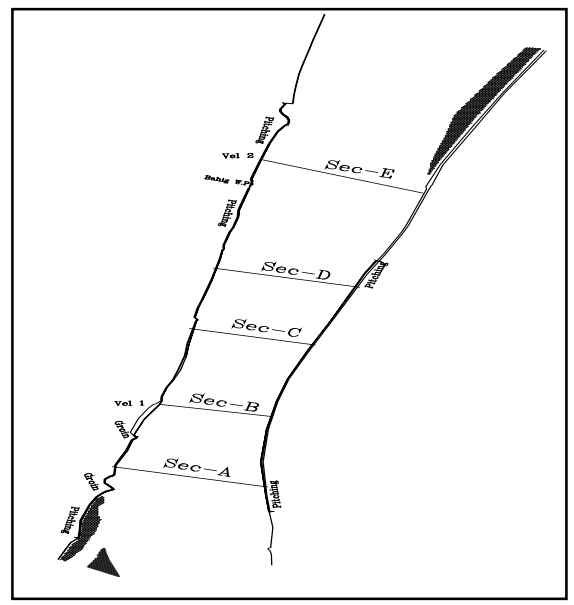

Fig.11 Location of the cross sections 


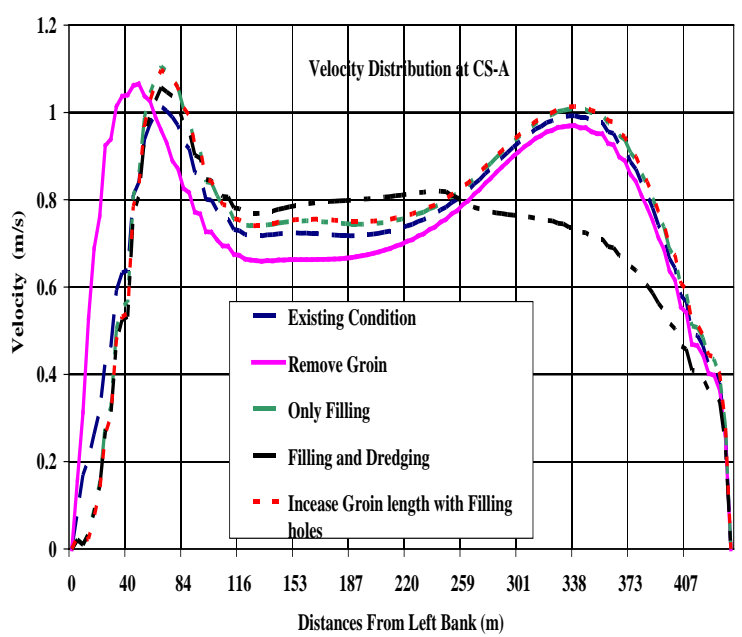

Fig.12 Velocity distribution at C. S A $\left(\mathrm{Q}=2066 \mathrm{~m}^{3} / \mathrm{s}\right)$

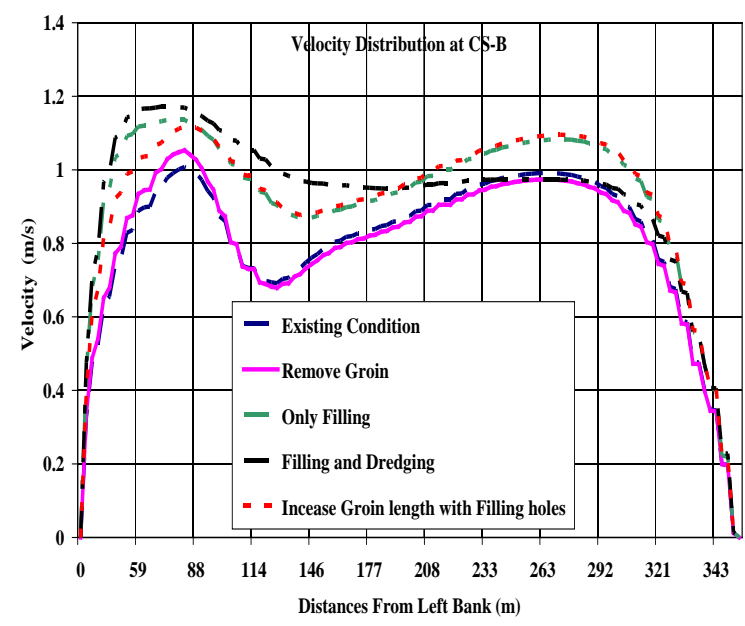

Fig.13 Velocity distribution at C. S B $\left(\mathrm{Q}=2066 \mathrm{~m}^{3} / \mathrm{s}\right)$

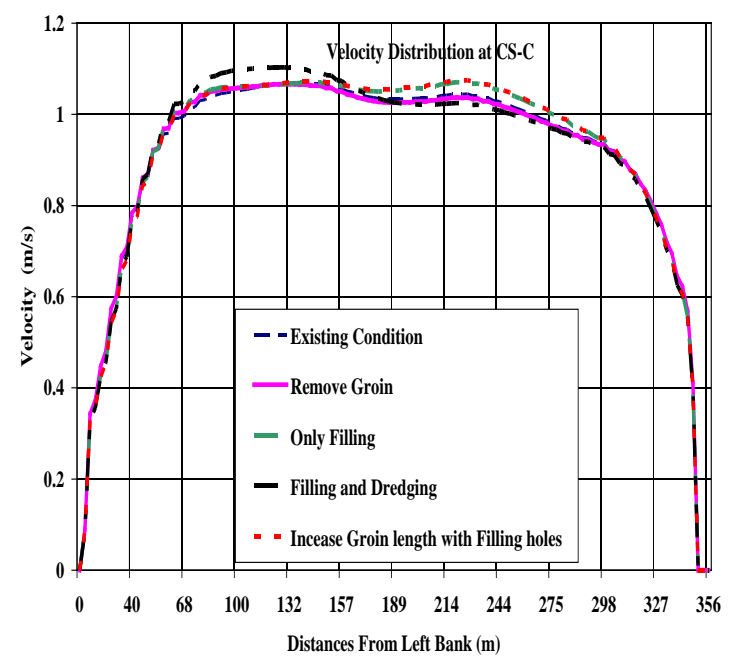

Fig.14 Velocity distribution at C. S C $\left(\mathrm{Q}=2066 \mathrm{~m}^{3} / \mathrm{s}\right)$

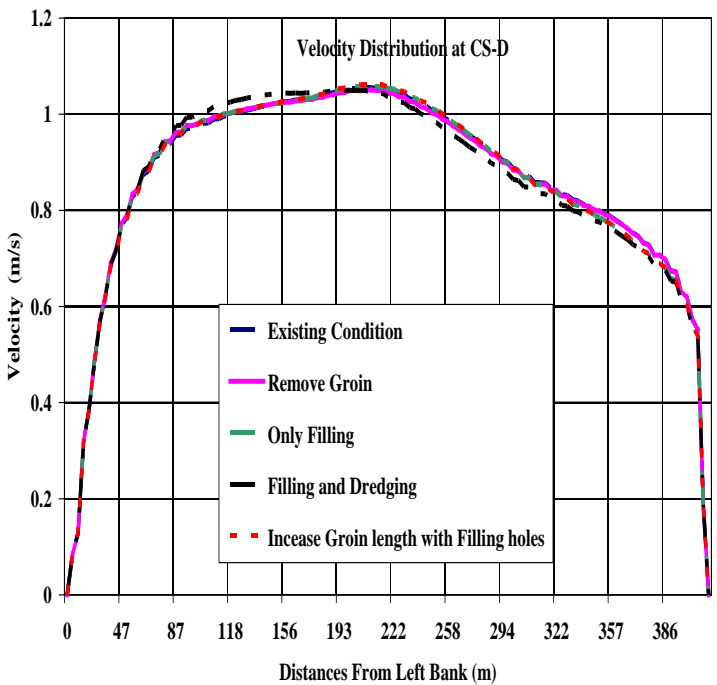

Fig.15 Velocity distribution at C.S (D) $\left(\mathrm{Q}=2066 \mathrm{~m}^{3} / \mathrm{s}\right)$

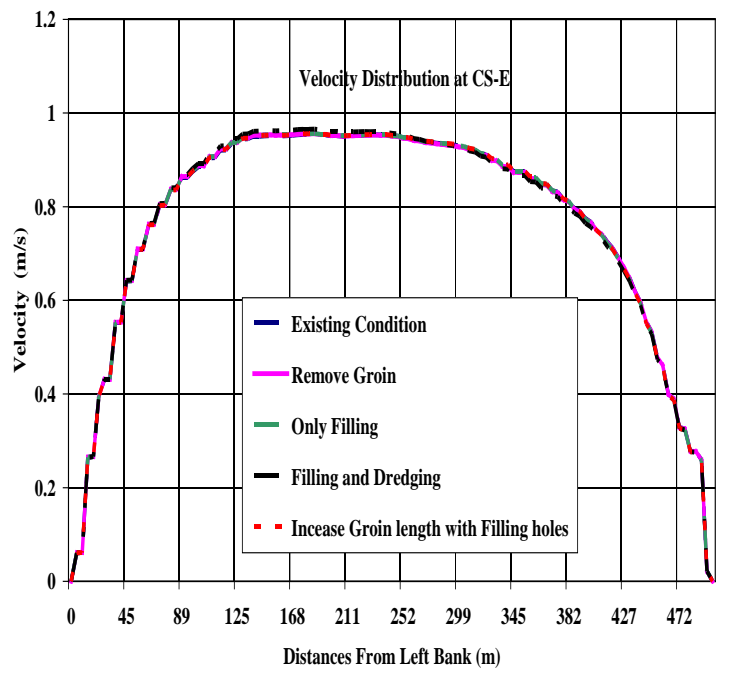

Fig.16 Velocity distribution at C.S (E) $\left(\mathrm{Q}=2066 \mathrm{~m}^{3} / \mathrm{s}\right)$

\subsection{Result Analysis}

1. In case of removing the groins, the maximum current velocity at cross sections A slightly increased and moved towards the western bank. Removing the groins did not influence the rest of the reach.

2. In case of filling the lowest parts of the scour holes to level $40 \mathrm{~m}$ above MSL, the current velocity at cross section A slightly increased at the middle and the western side, the current velocity increased along the cross section $B$ and the rest of the reach has not been influenced.

3. In case of filling the lowest parts of the scour holes to level $40 \mathrm{~m}$ above MSL and dredging the middle area to level $40 \mathrm{~m}$ above MSL, the current velocity at cross section $\mathrm{A}$ and $\mathrm{B}$ slightly increased at the middle and the western 
side and decreased at the eastern side at cross section A.

4. In case of increasing the groin at section 12 from $10 \mathrm{~m}$ to $60 \mathrm{~m}$ and filling the lowest parts at the western side to level $40 \mathrm{~m}$ above MSL, the current velocity have the same behavior as the previous mentioned in 2 and 3.

The considered western bank of river locates at the outer curve of a bend and the width of the river is very narrow at that part, so the momentum of the water movement is high. So, the proposed suggestions did not succeeded in decreasing the velocity at that area relative to the discharge which passes through it.

\section{CONCULOSION}

The western bank of the river outer curve located at $\mathrm{km} 552.4$ D.S. Aswan Dam suffers from bank instability due to high flood events. A reach of 2.8 $\mathrm{km}$ at that area was surveyed and it was found that there are two groins perpendicular to the western bank, three scour holes in the area of about of 1200 $\mathrm{m}$ long and $100 \mathrm{~m}$ width near to the western bank along the Salam village. The entire reach was simulated using hydrodynamic model. The model was calibrated using 2008 surveying data. In order to minimize the bank erosion and failure, the velocity near the western bank should be decreased. Different scenarios were suggested and simulated separately on the program as follows: (a) existing condition, (b) remove the located groin, (c) filling the lower part of areas (the scour holes) located at the western part to a level of $40.0 \mathrm{~m}$ above MSL,

(d) filling the bed and dredging the channel in areas closer to the scour hole until level of $40.0 \mathrm{~m}$ above
MSL and (e) extending the second groin from $10 \mathrm{~m}$ to $60 \mathrm{~m}$ length in addition to filling the lower part of scour hole to level of $40.0 \mathrm{~m}$ above MSL. The model results showed that the proposed suggestions did not decrease the velocity at the western part of the river where it locates at the outer curve.

Comparing the surveyed reach of 2008 with those of 2003 and 1982 showed that the centers of the scour holes did not move. The deepening of the scour holes almost the same except one of them if we compared between surveyed 2008 and 2003.

It is recommended to maintain the bank protection at that area where it established since 15 years ago and mentoring the scour holes should be done.

\section{REFERENCES}

[1] Hydraulic Engineering Circular No. 20, HEC 20, November 1995, "Stream Stability at Highway Structures", 2nd edition, Metric Version

[2] HRI-NWRC, Egypt (2005), "Protection of Bank against Erosion along the River Nile”, report No. 3/2005.

[3] Ibrahim S. A. S. and Bahggt M., Egypt (2009), "Study the Nile River western Bank at Salam village km 10.5 downstream Assuit Barrage", report No. 27/2009.

[4] River Nile Development Project, RNDP, (1991a, 1992b), "River Nile Bank Protection", NRI, NWRC, Ministry of Public Works and Water Resources, Egypt.

[5] River Nile Development Project, RNDP, (1989), "River Bank Erosion and Protection Methods", NRI, NWRC, Ministry of Public Works and Water Resources, Egypt. 